\title{
Osmoprotectant in soybean seeds can increase the inoculation and co- inoculation time in pre-sowing
}

\author{
Glauber Monçon Fipke ${ }^{1}$, Thomas Newton Martin ${ }^{1}$, Tânia Maria Müller ${ }^{2}$, Vinícius dos Santos Cunha ${ }^{1}$, \\ Janete Denardi Munareto ${ }^{1}$, Alex Tagliapietra Schönell ${ }^{1}$, Luiz Fernando Teleken Grando ${ }^{1}$, Anderson da \\ Costa Rossato ${ }^{1}$
}

\author{
${ }^{1}$ Department of Plant Science, Federal University of Santa Maria, Santa Maria, RS, Brazil \\ ${ }^{2}$ Department of Agronomy, University of Western Santa Catarina, Maravilha, SC, Brazil
}

\author{
*Corresponding author: gm.fipke@hotmail.com
}

\section{Abstract}

The practice of soybean seed inoculation cannot exceed the 24-hour prior to sowing. The objective of this study was to assess the effects of inoculation and co-inoculation of osmoprotectant soybean seeds, performed at different times of sowing. The experiments were conducted during two crop seasons at "sandy clay loam Acrisol" and "Cfa climate" in Santa Maria, RS, Brazil. The experimental design consisted of completely randomized blocks with four replications. Nine distinct treatments of seeds inoculation were carried out with bacteria of the genus Bradyrhizobium were inoculated alone (conventional inoculation) or combined with Azospirillum brasilense (co-inoculation), associated with the use of osmoprotectants. The components of nodulation, leaf chlorophyll, plant growth and grain yield were evaluated. The number of nodules and pods per plant are the variables most correlated with grain yield. Number of grains per pod, mass of thousand grains, and A, B and total chlorophyll content were not influenced by inoculation, co-inoculation and nitrogen fertilization. All treatments that used osmoprotectant had an increased $30 \%$ (in the first year) at average number of nodules in V5 compared to the treatments that did not use it. Coinoculation provided an increase of $31 \%$ and $16 \%$ of yield, respectively, compared to the no-inoculation treatment, for the first and second experimental years. Inoculation and co-inoculation when carried out seven days before sowing and associated with the use of the osmoprotector, provides grain yield similar to the inoculation performed at the time of sowing.

Keywords: Azospirillum brasilense; Bradyrhizobium spp.; Glicine max; pre-inoculation.

Abbreviations: BNF_biological nitrogen fixation, CFU_colony-forming units, PGPR_plant growth-promoting rhizobacteria, R3_pod formation (phenological stage), V5_five nodes (phenological stage).

\section{Introduction}

Inoculation of soybean seeds [Glycine max (L.) Merr.] with products containing bacteria of the genus Bradyrhizobium provides a symbiotic interaction of both organisms. Such "conventional" practice of inoculation has been considered indispensable (Embrapa, 2014). It is estimated that the biological nitrogen fixation (BNF) rates are higher than 300 $\mathrm{kg}$ of $\mathrm{N} \mathrm{ha}{ }^{-1}$, accounting for $94 \%$ of the total $\mathrm{N}$ required by the plant (Campo et al., 2009). Thus, high yields are obtained without addition of $\mathrm{N}$-fertilizers (Alves et al., 2006). Considering a soybean production of 5.6 tonne ha ${ }^{-1}$, total exports of grains correspond to $152 \mathrm{~kg}$ of N ha ${ }^{-1}$, and $29 \mathrm{~kg}$ of $\mathrm{N} \mathrm{ha}{ }^{-1}$ are left on the field as crop residues. This indicates that the total $\mathrm{N}$ amount is $181 \mathrm{~kg} \mathrm{ha}^{-1}$, i.e., $32.32 \mathrm{~kg}$ of synthetized $\mathrm{N}$ per ton of dry matter (Prado, 2008).

Azospirillum brasilense belongs to a group of plant growthpromoting rhizobacteria (PGPR), characterized by living freely in the soil and rhizosphere and may be beneficial to the plants. Mechanisms of promotion can be BNF, production of phytormones, increased root permeability, improved mineral absorption, and increased resistance to adverse conditions, such as drought, salinity and biochemicals compounds (Bashan and De-Bashan, 2010). A. brasilense-based inoculants are used in Poaceae plants such as maize, increasing grain productivities (Reis Junior et al., 2008). Co-inoculation is an association between two organisms, in this case, Bradyrhizobium sp. and Azospirillum sp.. This practice has contributed to increased yields of soybean cultures when supplied on seeds (Fipke et al., 2016) or when supplied in-furrow (Hungria et al., 2013), but the use of co-inoculation still requires further studies.

Some management relating to sowing-practices can affect the bacterial performance, among them phytosanitary treatment of the seeds with pesticides. According to Campo et al. (2009), this pratice can only be done if the soil and/or seeds are contaminated, once the bacterial cells viability diminishes when they are in contact with chemical agents 
(Bikrol et al., 2005). However, such recommendation has not been adopted by farmers, and today, in Brazil, nearly $100 \%$ of the soybean seeds are treated with fungicides and other chemical additives (Baudet and Peske, 2006). In this case, inoculation is done no later than 24 hours before sowing. Inoculation affects negatively the process logistics because it demands more workers and time to perform this practice (Hungria et al., 2013).

Pre-inoculation (anticipated inoculation) has been studied with satisfactory results, such as when this process is carried out a few days before sowing with no reduction on the soybean yield (Zilli et al., 2010). The use of osmoprotectants together with inoculant after the phytosanitary treatment provides the seed with a film coat that envelops it and minimizes the direct contact of the chemical products with the bacteria. In this case, biopolymers are used, which do not affect the physiological quality of the seeds and the nodulation process (Pereira et al., 2010). The osmoprotectant also acts in providing substrate (sugar solution) for the survival of the inoculum during the period that precedes symbiosis. In addition, substances that act in the genic expression in favor of nodule formation are released (Sugawara et al., 2006). This allows inoculation to be performed right after the chemical treatment of the seeds, extending the time available for sowing, without damage to the bacterial concentration in the seeds-surface. In the current literature many papers report the inefficiency of pre-inoculation when performed in the traditional way. With the insertion of new PGPR's and the use of seed osmoprotectants, new work is needed. The objective of this study was to assess the effects of inoculation and coinoculation of osmoprotectant soybean seeds, performed at different times in relation to sowing, on the morphological and nodulation characteristics and yield components.

Results

\section{Nodulation compounds}

Regarding the average number of nodules, during the experimental period of two years, the inoculated experiments provided higher averages compared to the noinoculation treatments. In the first year, the experiments with inoculation resulted in an average number of 58.8 nodules per plant, compared to 45.1 nodules per plant of the no-inoculation treatments, representing an average increase of $30 \%$ (V5), but in the second year, the nodulation increase represented $12.7 \%$ (Table 1 ). All treatments that used osmoprotectant were significantly better, with an average production of 60.6 nodules compared to 46.0 nodules in the no-inoculation experiments.

\section{Chlorophyll content compounds}

No statistical differences were observed in A, B and total chlorophyll content. The means obtained in the first year of experiments were superior in relation to the second one. This reduction has a great contribution of the chlorophyll $\mathrm{A}$ content, $13 \%$ lower in the second year.

\section{Plant growth compounds}

The shoot dry mass (V5) obtained different results in the two years of experiments. In the first year only the treatment with urea application $(\mathrm{NI}+\mathrm{N})$ differed statistically from the others, presenting an average reduction of $27 \%$. In the second, there was also a reduction for $\mathrm{BROS}_{7}$ and BROSAZO $_{10}$ treatments. For shoot dry mass (R3) the treatments $\mathrm{NI}+\mathrm{N}, \mathrm{BROS}_{10}$ and $\mathrm{BROSAZO}_{10}$ differ statistically in the two years of experiments, therefore, reduce the mass of plants.

The height of insertion of the first pod was lower for $\mathrm{NI}$ in the year 2013/14. In the other situations there was no significant difference. The total height of the plants was influenced by the addition of urea, with an increase in size.

\section{Grain yield compounds}

No statistical differences were observed in number of grains per pod and mass of thousand grains. The number of pods per plant showed best results in the treatments inoculated at the sowing day and seven days prior to sowing. For being typical characteristics of genetic improvements made in each cultivar and which do not present many variations, statistical differences were not found in the number of grains per pod as well as in thousand-grain mass.

The difference in grain yields was mainly influenced by the number of pods, presenting a significant correlation (Pearson) of 0.50 and 0.55 in the first and second year, respectively (Table 2). Thus, pre-inoculation sowing with Bradyrhizobium only (BROS 7 ) or in combination with Azospirillum brasilense (BROSAZO $\left.{ }_{7}\right)$, seven days prior to sowing showed to be effective, resulting in grain yield similar to the ones found with inoculation at the time of sowing. By establishing a relationship between the mean of treatments with the number of nodules per number of pods, it can be stated that each pod requires on average 1.11 nodules when the plant is at V5 and 2.05 nodules at R3. The correlation for these same variables is significant for the two-year experiments (0.63 and 0.37 , respectively), justifying the importance of the nodulation components and their influence on the grains yield (Table 2). Grains yield can be estimated by the number of nodules collected at V5, and the linear equation of this relation indicates that each nodule (plant ${ }^{-1} \mathrm{ha}^{-1}$ ) is responsible for the increase of 16.2 and $13.5 \mathrm{~kg}$ of grain ha ${ }^{-1}$ each growing season (Figure 2).

\section{Discussion}

The physical protection provided by the biopolymer contained in the osmoprotectant, there is presence of signaling molecules, called Nod factors. These substances are produced by the stimulation of the molecular signals excreted by the plant roots, which will be the future hosts of the bacterium (Sugawara et al., 2006). From such excretion, important proteins (nodulines) for the nodules formation and maintenance will be synthetized (Almaraz et al., 2007). The presence of such substances (Nod factor) provides a greater number of nodules in the initial stages of the crop. 


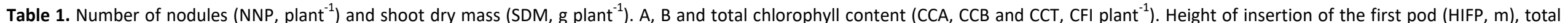

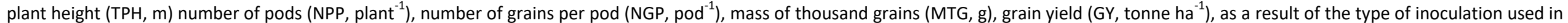
the soybean culture. Santa Maria, RS, Brazil.

\begin{tabular}{|c|c|c|c|c|c|c|c|c|c|c|c|c|c|}
\hline \multirow{2}{*}{$\begin{array}{l}\text { Phenological stage } \\
\text { Characters } \\
\text { Treatments }\end{array}$} & \multicolumn{4}{|c|}{--------------------------------V5----------------------------' } & \multirow[b]{2}{*}{ CCT } & \multicolumn{2}{|c|}{----------R3--------- } & \multicolumn{5}{|c|}{ 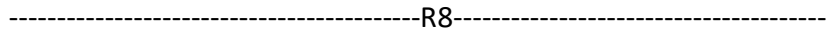 } & \multirow[b]{2}{*}{ GY } \\
\hline & NNP & SDM & CCA & $\mathrm{CCB}$ & & $\begin{array}{l}\text { NNP } \\
-2013 / 14\end{array}$ & SDM & HIFP & $\mathrm{TPH}$ & NPP & NGP & MTG & \\
\hline $\mathrm{NI}$ & $45.6 b^{*}$ & $25.0 \mathrm{a}$ & $31.8^{\mathrm{ns}}$ & $7.4^{\mathrm{ns}}$ & $38.9^{\mathrm{ns}}$ & $110.0 \mathrm{~b}$ & $61.1 \mathrm{a}$ & $0.26 \mathrm{~b}$ & $1.18 \mathrm{~b}$ & $41.6 \mathrm{c}$ & $2.3^{\mathrm{ns}}$ & $185.7^{\mathrm{ns}}$ & $2.98 \mathrm{~b}$ \\
\hline $\mathrm{NI}+\mathrm{N}$ & $44.7 \mathrm{~b}$ & $19.2 \mathrm{~b}$ & 32.1 & 7.5 & 39.2 & $100.0 \mathrm{~b}$ & $56.0 \mathrm{~b}$ & $0.29 a$ & $1.26 \mathrm{a}$ & $40.6 \mathrm{c}$ & 2.3 & 193.0 & $2.99 \mathrm{~b}$ \\
\hline I (Brady) & $47.8 \mathrm{~b}$ & $26.0 \mathrm{a}$ & 32.0 & 7.5 & 39.8 & $121.0 \mathrm{~b}$ & $64.4 \mathrm{a}$ & $0.26 \mathrm{~b}$ & $1.24 \mathrm{a}$ & $53.0 \mathrm{a}$ & 2.3 & 183.2 & $3.70 \mathrm{a}$ \\
\hline $\mathrm{BROS}_{0}$ & $67.7 \mathrm{a}$ & $24.8 \mathrm{a}$ & 31.9 & 7.5 & 39.3 & $141.6 \mathrm{a}$ & $63.9 \mathrm{a}$ & $0.32 \mathrm{a}$ & $1.25 \mathrm{a}$ & $56.4 \mathrm{a}$ & 2.3 & 185.7 & $3.74 \mathrm{a}$ \\
\hline $\mathrm{BROS}_{7}$ & $56.6 \mathrm{a}$ & $23.9 \mathrm{a}$ & 31.3 & 7.3 & 38.7 & $141.2 \mathrm{a}$ & $55.1 \mathrm{~b}$ & $0.24 \mathrm{~b}$ & $1.22 \mathrm{~b}$ & $53.2 \mathrm{a}$ & 2.4 & 185.7 & $3.55 \mathrm{a}$ \\
\hline BROS $_{10}$ & $59.1 \mathrm{a}$ & $24.4 \mathrm{a}$ & 31.5 & 7.6 & 39.2 & $118.4 \mathrm{~b}$ & $51.6 \mathrm{~b}$ & $0.23 \mathrm{~b}$ & $1.21 \mathrm{~b}$ & $48.8 \mathrm{~b}$ & 2.3 & 180.0 & $3.08 b$ \\
\hline BROSAZO $_{0}$ & $61.5 \mathrm{a}$ & $25.0 \mathrm{a}$ & 32.8 & 7.5 & 39.7 & 149.9 a & $68.9 \mathrm{a}$ & $0.25 \mathrm{~b}$ & $1.21 \mathrm{~b}$ & $58.8 \mathrm{a}$ & 2.3 & 178.0 & $3.91 \mathrm{a}$ \\
\hline $\mathrm{BROSAZO}_{7}$ & $61.2 \mathrm{a}$ & $23.6 \mathrm{a}$ & 32.8 & 7.8 & 40.7 & $112.0 \mathrm{~b}$ & $61.1 \mathrm{a}$ & $0.25 \mathrm{~b}$ & $1.23 \mathrm{a}$ & $52.9 \mathrm{a}$ & 2.3 & 185.0 & $3.58 \mathrm{a}$ \\
\hline BROSAZO $_{10}$ & $57.7 \mathrm{a}$ & $23.9 \mathrm{a}$ & 32.5 & 7.6 & 40.0 & $114.8 \mathrm{~b}$ & $57.4 \mathrm{~b}$ & $0.24 \mathrm{~b}$ & $1.21 \mathrm{~b}$ & $46.7 \mathrm{~b}$ & 2.3 & 184.0 & $3.44 b$ \\
\hline \multirow[t]{2}{*}{$\mathrm{CV} \%$} & 11.2 & 6.7 & 3.2 & 6.4 & 3.4 & 8.7 & 7.6 & 9.3 & 1.7 & 7.9 & 3.0 & 2.2 & 5.95 \\
\hline & \multicolumn{13}{|c|}{ } \\
\hline $\mathrm{NI}$ & $62.6 \mathrm{~b}$ & $23.8 \mathrm{~b}$ & $28.2^{\text {ns }}$ & $6.7^{\mathrm{ns}}$ & $35.3^{\mathrm{ns}}$ & $112.7^{\text {ns }}$ & $55.1 b$ & $0.18 b$ & $1.13 \mathrm{c}$ & $30.9 \mathrm{~b}$ & $2.2^{\mathrm{ns}}$ & $159.4^{\mathrm{ns}}$ & $3.09 \mathrm{c}$ \\
\hline $\mathrm{NI}+\mathrm{N}$ & $60.7 \mathrm{~b}$ & $25.3 \mathrm{a}$ & 28.7 & 7.7 & 36.3 & 91.6 & $56.0 \mathrm{~b}$ & $0.24 \mathrm{a}$ & $1.18 \mathrm{a}$ & $31.7 \mathrm{~b}$ & 2.1 & 161.3 & $3.02 c$ \\
\hline I (Brady) & $62.7 \mathrm{~b}$ & $25.1 \mathrm{a}$ & 28.6 & 7.3 & 35.7 & 135.3 & $64.4 \mathrm{a}$ & $0.22 \mathrm{a}$ & $1.13 \mathrm{c}$ & $44.9 \mathrm{a}$ & 2.1 & 164.2 & $3.48 a$ \\
\hline $\mathrm{BROS}_{0}$ & $73.7 \mathrm{a}$ & $24.8 \mathrm{a}$ & 27.3 & 7.1 & 35.0 & 134.2 & $63.9 \mathrm{a}$ & $0.23 \mathrm{a}$ & $1.15 \mathrm{~b}$ & $43.8 \mathrm{a}$ & 2.1 & 164.1 & $3.61 \mathrm{a}$ \\
\hline $\mathrm{BROS}_{7}$ & $71.2 \mathrm{a}$ & $24.4 \mathrm{~b}$ & 28.7 & 6.8 & 35.7 & 133.4 & $61.2 \mathrm{a}$ & $0.23 \mathrm{a}$ & $1.12 \mathrm{c}$ & $39.8 \mathrm{a}$ & 2.1 & 161.6 & $3.49 a$ \\
\hline BROS $_{10}$ & $73.0 \mathrm{a}$ & $25.2 \mathrm{a}$ & 27.9 & 7.0 & 36.0 & 120.4 & $51.6 \mathrm{~b}$ & $0.22 \mathrm{a}$ & $1.13 \mathrm{c}$ & $41.2 \mathrm{a}$ & 2.1 & 166.9 & $3.25 c$ \\
\hline $\mathrm{BROSAZO}_{0}$ & $77.8 \mathrm{a}$ & $24.8 \mathrm{a}$ & 28.3 & 6.4 & 34.5 & 133.5 & $68.9 \mathrm{a}$ & $0.23 \mathrm{a}$ & $1.15 \mathrm{~b}$ & $46.4 \mathrm{a}$ & 2.1 & 170.4 & $3.61 \mathrm{a}$ \\
\hline $\mathrm{BROSAZO}_{7}$ & $70.0 \mathrm{a}$ & $24.6 \mathrm{a}$ & 28.2 & 6.5 & 34.7 & 122.1 & $61.1 \mathrm{a}$ & $0.23 \mathrm{a}$ & $1.09 \mathrm{c}$ & $43.8 \mathrm{a}$ & 2.0 & 165.8 & $3.34 b$ \\
\hline BROSAZO $_{10}$ & $58.2 \mathrm{~b}$ & $24.1 \mathrm{~b}$ & 27.5 & 6.4 & 34.9 & 129.5 & $57.4 \mathrm{~b}$ & $0.22 \mathrm{a}$ & $1.11 \mathrm{c}$ & $40.5 \mathrm{a}$ & 2.1 & 166.6 & $3.37 \mathrm{~b}$ \\
\hline CV\% & 6.7 & 1.5 & 1.7 & 6.2 & 1.7 & 17.2 & 10.7 & 7.9 & 1.96 & 17.2 & 2.9 & 2.8 & 4.08 \\
\hline
\end{tabular}

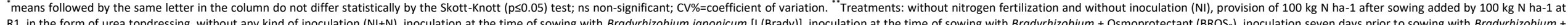

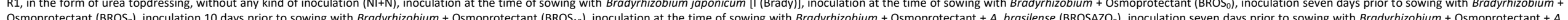
brasilense (BROSAZO 7 ), and inoculation 10 days prior to sowing with Bradyrhizobium + Osmoprotectant $+A$. brasilense (BROSAZO $\left.{ }_{10}\right)$. 


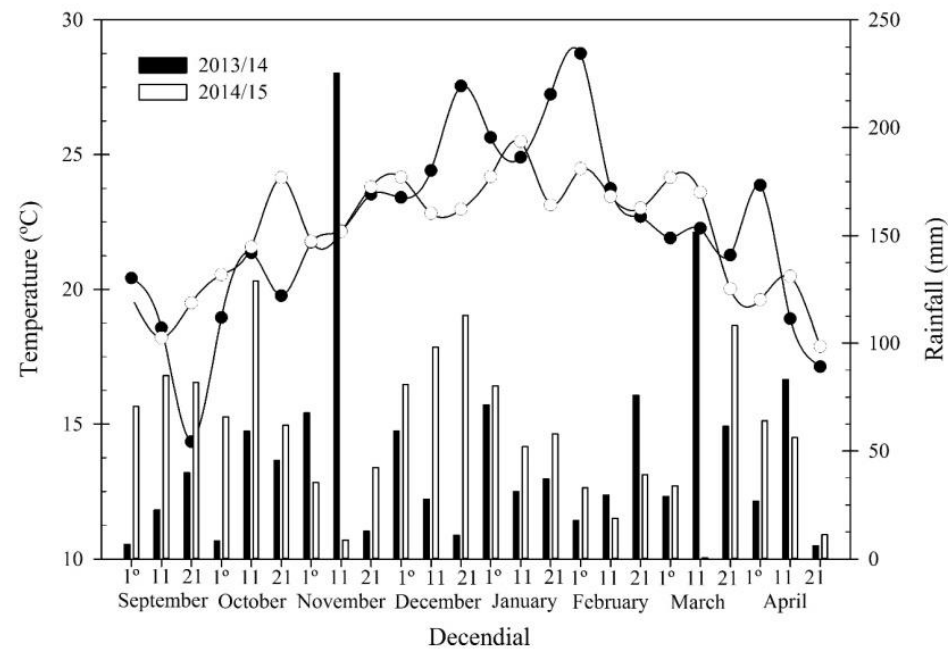

Fig 1. Mean temperatures $(\stackrel{\circ}{ }$ ) ) and accumulated precipitation $(\mathrm{mm})$ during the experimental period in 2013/14 and 2014/15 growing seasons. Santa Maria, RS, Brazil.

Table 2. Simple correlation between the explanatory variables in soybean culture in the 2013/14 growing seasons (regular font) and 2014/15 (bold). Santa Maria, RS, Brazil.

\begin{tabular}{|c|c|c|c|c|c|c|c|c|c|c|}
\hline $\mathrm{VE}^{1}$ & $\mathrm{NNP}_{\mathrm{v} 5}$ & $\mathrm{SDM}_{\mathrm{V} 5}$ & $\mathrm{NNP}_{\mathrm{R} 3}$ & $\mathrm{SDM}_{\mathrm{R} 3}$ & HIFP & TPH & NPP & NGP & MTG & GY \\
\hline $\mathrm{NNP}_{\mathrm{V} 5}{ }^{2}$ & --- & $0.22^{\text {ns }}$ & $0.12^{\text {ns }}$ & $0.26^{\mathrm{ns}}$ & $0.07^{\text {ns }}$ & $-0.09^{n s}$ & $0.37^{*}$ & $-0.14^{\mathrm{ns}}$ & $0.23^{\mathrm{ns}}$ & $0.42^{* *}$ \\
\hline $\mathrm{PDM}_{\mathrm{V} 5}$ & $0.19^{\mathrm{ns}}$ & --- & $-0.08^{\mathrm{ns}}$ & $0.17^{\text {ns }}$ & $0.32^{\mathrm{ns}}$ & $0.32^{*}$ & $0.26^{\mathrm{ns}}$ & $-0.16^{\mathrm{ns}}$ & $0.06^{\mathrm{ns}}$ & $0.16^{\mathrm{ns}}$ \\
\hline $\mathrm{NNP}_{\mathrm{R} 3}$ & $0.32^{*}$ & $0.33^{\mathrm{ns}}$ & --- & $0.15^{\mathrm{ns}}$ & $0.10^{\mathrm{ns}}$ & $-0.13^{\mathrm{ns}}$ & $0.16^{\text {ns }}$ & $0.15^{\mathrm{ns}}$ & $0.58^{* *}$ & $0.54^{* *}$ \\
\hline $\mathrm{PDM}_{\mathrm{R} 3}$ & $0.15^{\mathrm{ns}}$ & $0.34^{*}$ & $0.26^{\mathrm{ns}}$ & --- & $0.16^{\mathrm{ns}}$ & $0.22^{\text {ns }}$ & $0.09^{\text {ns }}$ & $-0.10^{\mathrm{ns}}$ & $0.36^{*}$ & $0.41^{*}$ \\
\hline HIFP & $-0.40^{*}$ & $-0.18^{\mathrm{ns}}$ & $-0.15^{\mathrm{ns}}$ & $0.09^{\mathrm{ns}}$ & --- & $0.17^{\text {ns }}$ & $0.28^{\mathrm{ns}}$ & $-0.38^{*}$ & $0.12^{\mathrm{ns}}$ & $0.11^{\text {ns }}$ \\
\hline TPH & $0.14^{\text {ns }}$ & $-0.28^{\mathrm{ns}}$ & $-0.03^{\mathrm{ns}}$ & $-0.08^{\text {ns }}$ & $0.23^{\mathrm{ns}}$ & -- & $-0.30^{\mathrm{ns}}$ & $0.01^{\text {ns }}$ & $-0.06^{\mathrm{ns}}$ & $-0.05^{\mathrm{ns}}$ \\
\hline NPP & $0.63^{* *}$ & $0.23^{\mathrm{ns}}$ & $0.60^{* *}$ & $0.24^{\mathrm{ns}}$ & $-0.42^{* *}$ & $-0.06^{\mathrm{ns}}$ & --- & $-0.34^{*}$ & $0.17^{\text {ns }}$ & $0.55^{* *}$ \\
\hline NGP & $-0.04^{\mathrm{ns}}$ & $0.12^{\text {ns }}$ & $0.07^{\text {ns }}$ & $-0.10^{\text {ns }}$ & $0.04^{\mathrm{ns}}$ & $0.06^{\text {ns }}$ & $-0.06^{\mathrm{ns}}$ & -- & $0.01^{\text {ns }}$ & $-0.23^{\mathrm{ns}}$ \\
\hline MTG & $-0.25^{\mathrm{ns}}$ & $-0.48^{* *}$ & $-0.40^{*}$ & $-0.12^{\mathrm{ns}}$ & $0.39^{*}$ & $0.20^{\mathrm{ns}}$ & $-0.45^{* *}$ & $0.07^{\mathrm{ns}}$ & --- & $0.37^{* *}$ \\
\hline GP & $0.36^{*}$ & $0.34^{*}$ & $0.53^{* *}$ & $0.41^{*}$ & $-0.04^{\mathrm{ns}}$ & $0.10^{\mathrm{ns}}$ & $0.50^{* *}$ & $0.07^{\mathrm{ns}}$ & $-0.24^{\mathrm{ns}}$ & --- \\
\hline
\end{tabular}

$\cdots$ and ${ }^{\text {ns }}$ : significant by t-test at $5 \%$ error probability and non-significant at $1 \%$ error probability; ${ }^{1}$ explanatory variables: number of nodules per plant (NNP, plant $\left.{ }^{-1}\right)$; shoot dry matter (SDM, $\mathrm{g}$ plant

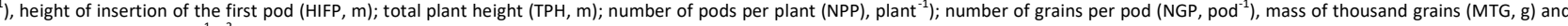
grains yield (GY, tonne ha $^{-1}$ ); ${ }^{2}$ phenologial stage (FEHR et al., 1971), V5; R3 and R8.
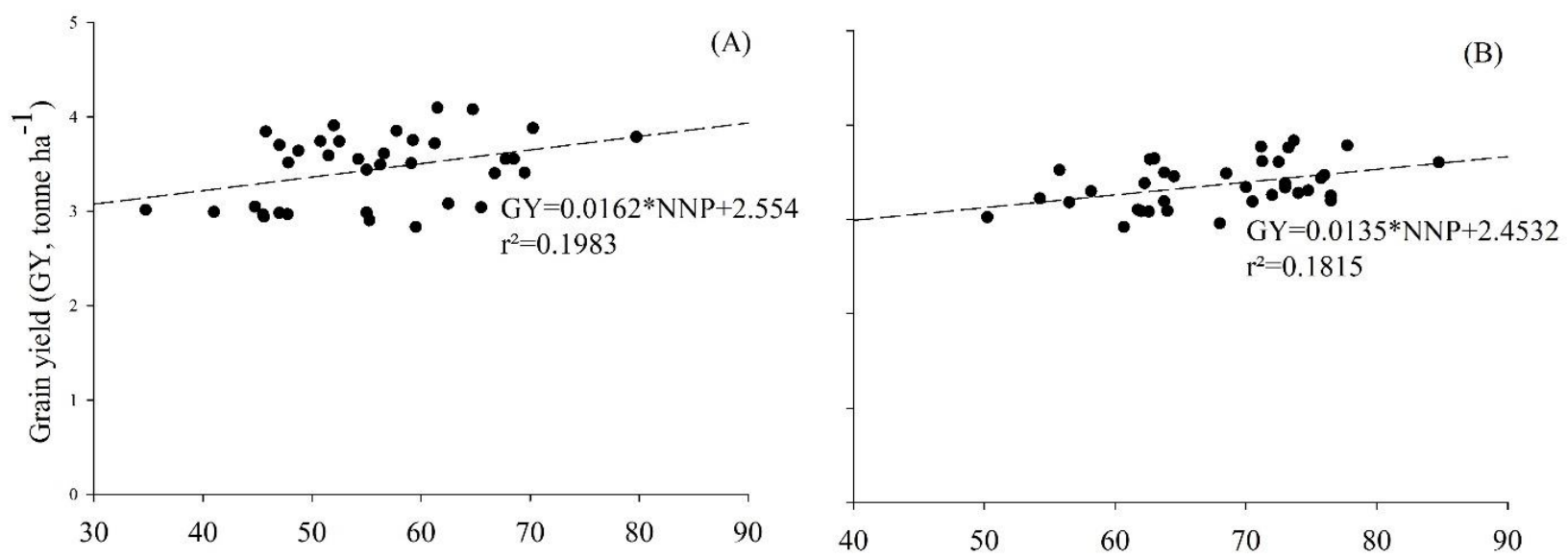

Number of nodules (NNP, plant $^{-1}$ ) show at V5 stage in 2013/14 (A) and 2014/15 (B).

Fig 2. Graph of distribution and linear equation relating to soybean grains yield and number of nodules. Santa Maria, RS, Brazil. 
No statistical differences were observed in A, B and total chlorophyll content, probably because the soybean culture has a higher capacity of homogenization of this parameter in the early stages (V5) or even because of the lack of a standard measurement method for this culture, as for common beans (Oliveira et al., 2012). Despite not existing a significant variation, plants nodulation was emphasized by Vollmann et al. (2011), who found a relation with increased chlorophyll contents in the leaves. Due to the high correlation between the chlorophyll content and nitrogen content in the plants (Argenta et al., 2001), this assessment confirms the efficiency of the diazotrophs, or nitrogen-fixing bacteria (Pereira et al., 2010), when the methodology of use of the equipment and the culture are fully consolidated.

$\mathrm{N}$-fertilizer provided a reduced number of nodules, mass of plant dry matter, number of pods and grain yields (Table 1). Regarding the second year of the experiment, the behavior was similar in terms of number of nodules and pods and grain yields. The treatments with urea resulted in more insertions of the first pod and total height. However, this situation may not be favorable, because it can cause bedding with increased distance between nodes. The use of $\mathrm{N}$ fertilizer proved to be unnecessary, corroborating results obtained on the Brazilian cerrado, or savanna (Mendes et al., 2008; Petter et al., 2012). Even when small doses are added, $\mathrm{N}$-fertilizer absorbed as ammonium can hinder BNF, because of a possible partial inactivation of the enzyme nitrogenase, which may or may not be reversible (Rudnick et al., 1997). In this experiment, $222 \mathrm{~kg} \mathrm{ha}^{-1}$ of urea (100 kg de N) was applied soon after sowing, which affected directly the diazotrophs activity. Regarding the plants height, an overall mean value of $1.22 \mathrm{~m}$ in total height was observed in the first year, which is higher than the values found by Rezende and Carvalho (2007), who stated that plant heights suitable to mechanical harvesting are in between 0.6 and $1.20 \mathrm{~m}$. The less amount of nodes in the main stem results in lower values of the height of insertion of the first pod and total pods, and cycle reduction. This initial period is responsible for the growth and structuring of the plants productive organs, which will be later responsible for the grains production (Ludwig et al., 2010).

About pre-inoculation, Zilli et al. (2010) obtained similar results with inoculation anticipated to five days before sowing, in normal environmental conditions, as long as the seeds had not been treated with fungicides. Current Brazilian legislation states that inoculants with bacterial symbionts must ensure $1 \times 10^{9}$ per gram or milliliter of formulated product (Brasil, 2011). Possibly, in the present work, the storage time of the inoculated seeds has extended two days because the inoculant used has a greater bacterial load (7 times more) and was used in conjunction with the osmoprotectant, thus diminishing the effect of the seeds treatment with fungicides and insecticides.

With regard to the co-inoculation, it has presented contradictory responses as to yields, i.e., promoting increases (Hungria et al., 2013) and insignificant yield increases (Bárbaro et al., 2009). This corroborates the results of this study, which found an increase of $31 \%$ in relation to the no-inoculation treatment and an increase of only $5 \%$ over the treatment inoculated with Bradyrhizobium alone, in the first year of the experiment. In this same comparison Fipke et al. (2016) obtained increases at 4\% (0.24 tonne of grains $\mathrm{ha}^{-1}$ ) however, without statistical difference. In water stress conditions, Benintende et al. (2010) found that coinoculation increased considerably the mass of nodules, but it had no statistical difference in the grains yield when compared to the inoculation with Bradyrhizobium japonicum. However, under water stress, there was no difference. In the present study, in the second year of the experiments there were events of excessive rainfall and mean temperature below 25으 (Figure 1), explaining the divergence of result in relation to the previous year.

The demand for pre-inoculated seeds is growing (Deaker, 2004), therefore, coating with polymeric adhesives can provide an increased survival of rhizobia. According to the results of this work it becomes possible to inoculate the seeds prior to day sowing. Thus, the farmer has the possibility to schedule the calendar of activities that precede the sowing. This will provide greater use of time and labor without compromising the economic return from grain yield. Another approach consists of using plant growth-promoting rhizobacteria, which requires further studies with respect to the root exudates and interaction with signaling molecules (Ryan et al., 2009). Such rhizobacteria can be manipulated and inserted into agricultural inoculants, becoming important biotechnology tools towards sustainability.

\section{Materials and methods}

\section{Site description}

The experiments were conducted in the experimental area of the Department of Plant Science of the Federal University of Santa Maria, located in the central region of the state of Rio Grande do Sul, Brazil, at 2942' south latitude, 5342' west longitude and 116 meters high, during two crop years. The soil in this area is classified as Argissolo Vermelho Distrófico típico (Embrapa, 2013) (a sandy clay loam Acrisol in the FAO classification). Before to sowing of the experiment of the first year they were collected soil samples ( 0 - $0.2 \mathrm{~m}$ deep). Fertilizer recommendations for soybeans was made based on chemical analysis. The nutrient availability ranges are established based on results of researches field, where the yield of the cultures in different soils, and for several years, is related to the levels of nutrients in the soil. It is designed a calibration curve for experctativa of 3 tonne of grain ha $^{-1}$ (CQFS, 2016). Chemical analysis of the soil indicates that it has the following characteristics: $\mathrm{pH}$ (water, 1:1) $=5.3$; organic matter $(\%$, $\mathrm{m} / \mathrm{v})=2.2$; clay $(\%, \mathrm{~m} / \mathrm{v})=23$; phosphorus, P-Mehlich $(\mathrm{mg}$ $\left.\mathrm{dm}^{-3}\right)=17.3$; potassium $\left(\mathrm{mg} \mathrm{dm}^{-3}\right)=84.0 ; \mathrm{H}+\mathrm{Al}\left(\mathrm{cmol}_{\mathrm{c}} \mathrm{dm}^{-3}\right)$ = 7.9; $\mathrm{Al}\left(\mathrm{cmol}_{\mathrm{c}} \mathrm{dm}^{-3}\right)=0.2$; cation exchange capacity $(\mathrm{pH} \mathrm{7}$, $\left.\mathrm{cmol}_{\mathrm{c}} \mathrm{dm}^{-3}\right)=14.7$; base saturation $(\%)=47.8$. The experimental area has been cultivated with wheat (winter) and soybean (summer) succession for three years. The climate in the region, according to Köppen climate classification, is Cfa (Peel et al., 2007), a humid subtropical climate, with the mean temperature in the warmest month of $24.8^{\circ} \mathrm{C}$ and $14.1^{\circ} \mathrm{C}$ in the coldest month (Heldwein et al., 2009). The climate data on growing seasons are shown in Figure 1. 


\section{Soil bacterial diversity}

Populations of microorganisms naturally present at the experimental site were determined by sampling the soil and the plants root tissue. The samples were collected and taken to the laboratory. The bacterial diversity was then estimated by the number of gene sequences found. An extensive database was generated due to specificity of the methodology. It was defined that only the bacterial genera studied here would be taken into account, being represented by the number of traits. A DNA sequencer was used (Illumina Misec ${ }^{\circ}$ System), through which 1382 traces of bacterial diversity were determined, of which $1.69 \times 10^{-2}$ were traces of Bradyrhizobium spp., and none of Azospirillum brasilense (data not shown).

\section{Soil and sowing management}

The $\mathrm{pH}$ level of the experimental site was adjusted by the application of agricultural lime 90 days prior to sowing ( 3 tonne $\mathrm{ha}^{-1}$ ), which was incorporated to the topsoil by disking, and subsequently wheat was sown. Forty days prior to soybean sowing, wheat was desiccated with glyphosate (Roundup , $360 \mathrm{~g}$ active ingredient (a.i.) $\mathrm{L}^{-1}$ commercial product (c.p.) at a dose of $3 \mathrm{~L} \mathrm{ha}^{-1}$ ), providing dry matterof 4 tonne $\mathrm{ha}^{-1}$. The experiments were implemented in no-till system with a fertilizer seeder on November 15, 2013 (crop season 2013-2014) and December 15, 2014 (crop season 2014-2015). The soybean cultivar used was TEC 6029 IPRO [Cooperativa Central Gaúcha Ltda. (CCGL)], characterized by indeterminate growth type, relative maturity group 5.7. Sowing density consisted of 16 seeds per linear meter, spaced at $0.45 \mathrm{~m}$ between rows. After seedling emergence was made the pull-off (roughing) to ensure a population of 290,000 plants ha ${ }^{-1}$. Two hundred $\mathrm{kg} \mathrm{ha}^{-1}$ of formulated fertilizer without nitrogen, $23 \%$ of phosphorus and $30 \%$ of potassium (00-23-30), were applied to the sowing furrow.

\section{Phytosanitary management}

The seeds phytosanitary treatment was performed 12 days prior to sowing, using pyraclostrobin + thiophanate-methyl and fipronil (Standak Top , 25, 225 and $250 \mathrm{~g}$ a.i. $\mathrm{L}^{-1}$ at a dose 0,2 L c.p. $100 \mathrm{~kg}$ seeds $^{-1}$ ). About the main pest management: for weed (Eleusine indica and Ipomoea sp.) was used glyphosate (Roundup , $360 \mathrm{~g}$ a.i. $\mathrm{L}^{-1}$ c.p. at a dose of $1.5 \mathrm{~L} \mathrm{ha}^{-}$ $\left.{ }^{1}\right)$ applied to V4 [four nodes and third trifoliate leaf fully developed, 35 days after emergence (Fehr et al., 1971); for insects caterpillars (Spodoptera eridania and Helicoverpa sp.) was used clorantraniliprole (Premio , $200 \mathrm{~g}$ a.i. $\mathrm{L}^{-1}$ at a dose of 0,05 L p.c. ha ${ }^{-1}$ ) applied inV5 (five nodes and four fully developed trifoliate leaves), bugs (Nezara viridula and Euschistus heros) was used tiametoxan + lambda-cialotrina (Engeo Pleno , 141 and $106 \mathrm{~g}^{\circ}$ a.i. $\mathrm{L}^{-1}$ at a dose of 0,2 L c.p. ha $\left.{ }^{1}\right)$ applied in R4 (full pod formation); for deseases (Corynespora cassiicola and Phakopsora pachyrhizi) was used trifloxistrobrina + protioconazol (Fox, 167 and $333 \mathrm{~g}$ a.i. $L^{-1}$ at a dose of 0,3 L c.p. ha ${ }^{-1}$ ) applied in V4 and fluxapiroxidade + piraclostrobina (Orkestra, 150 and $175 \mathrm{~g}$ a.i. $L^{-1}$ at a dose of 0,3 L c.p. ha ${ }^{-1}$ ) applied in R4. All pesticides were applied with costal sprayer electric. Management of the crop followed the technical general guidelines for soybean cultures (Embrapa, 2014).

\section{Description of treatments and experimental design}

An inoculant containing bacteria of the genus Bradyrhizobium, B. japonicum strain CPAC 15 (SEMIA 5079) and B. diazoefficiens (Delamuta et al., 2013) strain CPAC 7 (SEMIA 5080) (Total Nitro Full', Total Biotecnologia, Curitiba, $\mathrm{PR}, \mathrm{Brazil})$ was used, with guaranteed $7 \times 10^{9}$ colony-forming units (CFU mL ${ }^{-1}$ of c.p.), at a dosage of $0.002 \mathrm{~L} \mathrm{~kg}^{-1}$ of seeds. Also used as an inoculant containing bacteria of the genus Azospirillum brasilense, strains Ab-V5 and Ab-V6 (AzoTotal, Total Biotecnologia, Curitiba, PR, Brazil), with guaranteed population of $2 \times 10^{8} \mathrm{CFU} \mathrm{mL}-1$, at a dosage of $0.002 \mathrm{~L} \mathrm{~kg}^{-1}$ of seeds. The seed osmoprotectant (Protege TS, Total Biotecnologia, Curitiba, PR, Brazil) contains bacterial signaling molecules named "Nod factor", a complex of sugars and biopolymers, at the dosage of $0.001 \mathrm{~L} \mathrm{~kg}^{-1}$ of seeds.

Nine distinct treatments of seeds inoculation were carried out: (i) without nitrogen fertilization and without inoculation (NI); (ii) provision of $100 \mathrm{~kg} \mathrm{~N} \mathrm{ha}^{-1}$ after sowing added by 100 $\mathrm{kg} \mathrm{N} \mathrm{ha}^{-1}$ at R1, in the form of urea topdressing, without any kind of inoculation $(\mathrm{NI}+\mathrm{N})$; (iii) inoculation at the time of sowing with Bradyrhizobium japonicum [I (Brady)]; (iv) inoculation at the time of sowing with Bradyrhizobium + Osmoprotectant $\left(\mathrm{BROS}_{0}\right)$; $(\mathrm{v})$ inoculation seven days prior to sowing with Bradyrhizobium + Osmoprotectant $\left(\mathrm{BROS}_{7}\right)$; (vi) inoculation 10 days prior to sowing with Bradyrhizobium + Osmoprotectant $\left(\mathrm{BROS}_{10}\right.$ ); (vii) inoculation at the time of sowing with Bradyrhizobium + Osmoprotectant $+A$. brasilense (BROSAZO $)$; (viii) inoculation seven days prior to sowing with Bradyrhizobium + Osmoprotectant $+A$. brasilense ( $\left.\mathrm{BROSAZO}_{7}\right)$, and (ix) inoculation 10 days prior to sowing with Bradyrhizobium + Osmoprotectant $+A$. brasilense $\left(\mathrm{BROSAZO}_{10}\right)$. For the purpose of recommending the use of inoculants containing diazotrophic bacteria, the Brazilian protocol (Brasil, 2007) was used. Thus, the use of the first three treatments is justified, in order to compare (i) the absence of inoculation; (ii) the culture response if fertilized with $\mathrm{N}$-mineral and (iii) the use of an inoculant already registered and recommended for culture. The seeds inoculated prior to sowing were stored in paper bags in dry place with constant temperature of $25 \circ \mathrm{C}$ and constant relative humidity of $60 \%$.

The experimental design consisted of completely randomized blocks with four replications. The plots consisted of five rows measuring seven meters long and 2.25 meters wide $\left(15.75 \mathrm{~m}^{2}\right)$.

\section{Explanatory variables}

The explanatory variables were assessed at the plant growth stage V5 (fifth node and fourth trifoliate leaf fully developed), at the reproductive stage R3 (start of pod formation), and at physiological maturity R8 (full maturity of $95 \%$ of pods).

Four plants were marked for assessment of nodulation and plants mass at stage V5, and another four plants for the same evaluations at R3. After being collected, the aerial portion of the plant was removed and dried $\left(60^{\circ} \mathrm{C}\right)$ to constant weight for measuring the shoot dry mass (SDM, $g$ 
plant $\left.^{-1}\right)$. The roots were washed, and the number of nodules per plant was counted (NNP, plant ${ }^{-1}$ ) considering all nodules present on the taproot and secondary roots larger than 2 $\mathrm{mm}$ diameter. To estimate the chlorophyll content (A, B and total), ten random measurements were taken in the parcel, at the central trefoil of the last but one trifoliate leaf that was fully developed, from the apex to the base. We used the clorofiLOG ${ }^{\circ}$ (CFL 1030, Falker) chlorophyll meter to estimate the Falker chlorophyll index ( $\mathrm{FCl}$ plant $\left.{ }^{-1}\right)$. Five plants were marked for assessment of growth and yield components at R8. The height of insertion of the first pod (HIFP, $m$ ) and the total plants height (TPH, $\mathrm{m}$ ), were measured. The number of pods per plant (NPP, plant ${ }^{-1}$ ) was obtained by counting separating the pods containing one, two and three grains for calculating the number of grains per pod (NGP, pod ${ }^{-1}$ ). It was made manual harvesting of the useful area of the plot (five meters long in the three central rows of the parcel, $6.75 \mathrm{~m}^{2}$ ), mechanical track and threshing, being corrected based grain moisture to $13 \%$, then, the grains yield (GY, tonne $\mathrm{ha}^{-1}$ ) and the mass of thousand grains (MTG, g) were estimated.

\section{Statistical analyses}

Data were subjected to tests of assumptions of the mathematical model and were not violated (Steel and Torrie, 1997). Later, analysis of variance (F-test) was conducted, and when statistical difference was confirmed, a post hoc test [Scott-Knott $(p \leq 0.05)]$ was applied using the statistical software Sisvar (Ferreira, 2011).

\section{Conclusion}

The use of osmoprotectant for inoculation with Bradyrhizobium alone (conventional inoculation) or combined with Azospirillum brasilense (co-inoculation) seven days prior to sowing provided grain yield similar to the inoculation performed at the time of sowing.

\section{Acknowledgements}

The authors would like to thank the Higher-Level Personnel Improvement Coordination (Capes-Brazil) for the scholarship provided, The National Council for Scientific and Technological Development (CNPq).

\section{References}

Almaraz JJ, Zhou X, Souleimanov A, Smith D (2007) Gas exchange characteristics and dry matter accumulation of soybean treated with Nod factors. J Plant Physiol. 164:1391-1393.

Alves BJR, Zotarelli L, Fernandes FM, Heckler JC, Macedo RAT de, Boddey RM, Jantalia CP, Urquiaga S (2006) Biological nitrogen fixation and nitrogen fertilizer on the nitrogen balance of soybean, maize and cotton. Pesqui Agropecuária Bras. 41:449-456.

Argenta G, Silva PRF da S, Bortolini CG, Forsthofer EL, Strieder ML (2001) Relationship of reading of portable chlorophyll meter with contents of extractable chlorophyll and leaf nitrogen in maize. Rev Bras Fisiol Veg. 13:158167.

Bárbaro IM, Machado PC, Junior LSB, Ticelli M, Miguel FB, Silva JAA da (2009) Produtividade da soja em resposta á inoculação padrão e co-inoculação. Colloq Agrar. 51:1-7.

Bashan Y, De-Bashan LE (2010) How the plant growthpromoting bacterium Azospirillum promotes plant growth - A critical assessment. Adv Agron. 108:77-126.

Baudet L, Peske ST (2006) A logística do tratamento de sementes. Seed News. 10:20-23.

Benintende S, Uhrich W, Herrera M, Gangge F, Sterren M, Benintende M (2010) Comparación entre coinoculación com Bradyrhizobium japonicum y Azospirillum brasilense e inoculación simple con Bradyrhizobium japonicum en la nodulación, crecimiento y acumulación de $\mathrm{N}$ en el cultivo de soja. Agriscientia. 27:71-77.

Bikrol A, Saxena N, Singh K (2005) Response of Glycine max in relation to nitrogen fixation as influenced by fungicide seed treatment. African J Biotechnol. 4:667-671.

Brasil. Ministério da Agricultura Pecuária e Abastecimento (2011) Instrução Normativa $n^{\circ} 13$, de 24 de março de 2011. Available at: $<$ http://www.agricultura.gov.br/assuntos/insumosagropecuarios/insumosagricolas/fertilizantes/legislacao/in-sda-13-de-24-03-2011inoculantes.pdf $>$. Accessed on: October $11^{\text {th }}, 2018$.

Brasil. Ministério da Agricultura Pecuária e Abastecimento (2007) Protocolo oficial para avaliação da viabilidade e eficiência agronômica de cepas, inoculantes e tecnologias relacionados ao processo de fixação biológica do nitrogênio em leguminosas. Available at: $<$ http://www.agricultura.gov.br/assuntos/registro-deprodutos-e-estabelecimentos/arquivosrpe/IN132011inoculprotocoloprocfixbiologicadoNemlegu minosasalterado3512.pdf>. Accessed on: October $11^{\text {th }}$, 2018.

Campo RJ, Araujo RS, Hungria M (2009) Nitrogen fixation with the soybean crop in Brazil: Compatibility between seed treatment with fungicides and bradyrhizobial inoculants. Symbiosis. 48:154-163.

CQFS. Comissão de Química e Fertilidade do Solo (2016) Manual de calagem e adubação para os Estados do Rio Grande do Sul e Santa Catarina, 11th edn. Porto Alegre, Rio Grande do Sul.

Deaker R (2004) Legume seed inoculation technology - A review. Soil Biol Biochem. 36:1275-1288.

Delamuta JRM, Ribeiro RA, Ormeno-Orrillo E, Melo IS, Martinez-Romero E, Hungria M (2013) Polyphasic evidence supporting the reclassification of Bradyrhizobium japonicum group la strains as Bradyrhizobium diazoefficiens sp. nov. Int J Syst Evol Microbiol. 63:33423351.

Embrapa. Empresa Brasileira de Pesquisa Agropecuária (2014) Indicações Técnicas para a Cultura da Soja no Rio Grande do Sul e em Santa Catarina, safras 2014/2015 e 2015/2016. Available at: < http://ainfo.cnptia.embrapa.br/digital/bitstream/item/120 121/1/Indicacoes-Tecnicas-Embrapa-003.pdf >. Accessed on: October $11^{\text {th }}, 2018$.

Embrapa. Empresa Brasileira de Pesquisa Agropecuária (2013) Sistema Brasileiro de Classificação de Solos, 3rd edn. Brasília, Distrito Federal.

Fehr WR, Caviness CE, Burmood DT, Pennington JS (1971) Stage of development descriptions for soybeans, Glycine $\max ($ L.) Merrill1. Crop Sci. 11:929-931.

Ferreira DF (2011) Sisvar: a computer statistical analysis system. Ciência e Agrotecnologia. 35:1039-1042. 
Fipke GM, Conceição GM, Grando LFT, Ludwig RL, Nunes UR, Martin TN (2016) Co-inoculation with diazotrophic bacteria in soybeans associated to urea topdressing. Ciência e Agrotecnologia. 40:522-533.

Heldwein AB, Buriol GA, Streck NA (2009) O clima de Santa Maria. Ciência Ambient. 38:43-58.

Hungria M, Nogueira MA, Araujo RS (2013) Co-inoculation of soybeans and common beans with rhizobia and azospirilla: Strategies to improve sustainability. Biol Fertil Soils. 49:791-801.

Ludwig MP, Dutra LMC, Lucca Filho OA, Zabot L, Uhry D, Lisboa JI, Jauer A (2010) Morphologic characteristic of the conventional soybean genotype and Roundup Ready ${ }^{\mathrm{TM}}$ according to the sowing season and seed densities. Ciência Rural. 40:759-767.

Mendes I de C, Reis Junior FB dos, Hungria M, Sousa DMG de, Campo RJ (2008) Late supplemental nitrogen fertilization on soybean cropped in Cerrado Oxisols. Pesqui Agropecuária Bras. 43:1053-1060.

Oliveira TC de, Silva J, Sousa SA de, Campestrini R, Fidelis RR (2012) Yield potential of common bean cultivars in function of phosphorus stress in State of Tocantins. J Biotechnol Biodivers. 3:2179-4804.

Peel MC, Finlayson BL, McMahon TA (2007) Updated world map of the Köppen-Geiger climate classification. Hydrol Earth Syst Sci. 11:1633-1644.

Pereira CE, de Souza Moreira FM, Oliveira JA, Caldeira CM (2010) Compatibility among fungicide treatments on soybean seeds through film coating and inoculation with Bradyrhizobium strains. Acta Sci - Agron. 32:585-589.

Petter FA, Pacheco LP, Neto F de A, Santos GG (2012) Respostas de cultivares de soja à adubação nitrogenada tardia em solos de cerrado. Rev Caatinga. 25:67-72.

Prado R de M (2008) Nutrição de Plantas, 1st edn. São Paulo, São Paulo.

Reis Junior FB dos, Machado CT de T, Machado AT, Sodek L (2008) Inoculação de Azospirillum amazonense em dois genótipos de milho sob diferentes regimes de nitrogênio. Rev Bras Ciência do Solo. 32:1139-1146.

Rezende PM de, Carvalho E de A (2007) Avaliação de cultivares de soja [Glycine max (L.) Merrill] para o sul de Minas Gerais. Ciência e Agrotecnologia. 31:1616-1623.

Rudnick P, Meletzus D, Green A, He L, Kennedy C (1997) Regulation of nitrogen fixation by ammonium in diazotrophic species of proteobacteria. Soil Biol Biochem. 29:831-841.

Ryan PR, Dessaux Y, Thomashow LS, Weller DM (2009) Rhizosphere engineering and management for sustainable agriculture. Plant Soil. 321:363-383.

Steel RGD, Torrie JH (1997) Principles and procedures of statistics: a biometrical approach, 3th edn. New York, New York.

Sugawara M, Okazaki S, Nukui N, Ezura H, Mitsui H, Minamisawa K (2006) Rhizobitoxine modulates plantmicrobe interactions by ethylene inhibition. Biotechnol Adv. 24:382-388.

Vollmann J, Walter H, Sato T, Schweiger P (2011) Digital image analysis and chlorophyll metering for phenotyping the effects of nodulation in soybean. Comput Electron Agric. 75:190-195.

Zilli JÉ, Campo RJ, Hungria M (2010) Eficácia da inoculação de Bradyrhizobium em pré-semeadura da soja. Pesqui Agropecuária Bras. 45:335-337. 